\title{
Regional Foreign Direct Investment Potential in Selected African
} Countries

\author{
Philip Agyei Peprah ${ }^{1}$, Yao Hongxing ${ }^{1} \&$ Jean Baptiste Bernard Pea-Assounga ${ }^{1}$ \\ ${ }^{1}$ School of Finance and Economics, University of Jiangsu, Zhenjiang, PR China \\ Correspondence: Philip Agyei Peprah, School of Finance and Economics, University of Jiangsu, Zhenjiang \\ 212013, PR China. Tel: 86-511-8879-2098. E-mail: hxyao@ujs.edu.cn
}

Received: July 15, 2019

Accepted: September 1, $2019 \quad$ Online Published: September 20, 2019

doi:10.5539/ijef.v11n10p66

URL: https://doi.org/10.5539/ijef.v11n10p66

\begin{abstract}
The recent devolutionary trend across the world has been in part fuelled by claims of a supposed 'economic growth by direct investment dividend' associated with the fiscal decentralization. There is however, little empirical evidence to substantiate these claims. Most prior research has determined different research techniques of measurement by generating mix results. More so, these studies do not differentiate between short and long run techniques and mechanisms through which county expenditure affects economic growth, by investment growth, and by foreign reserve of African countries. The background has investigated empirically the short and long run techniques effect of components of county expenditure on economic growth investment, by foreign direct investment growth in the African countries in period of 2013 to 2017. The variables tested by unit root by no stationary at interval levels. The long and short run of variables computed by ARDL methods by Keynesian theory. However, the budget allocation and execution improved to capital infrastructure and like transport communication help to improve private capital accumulation and economic growth.
\end{abstract}

Keywords: African countries, counties, expenditure, economic growth by foreign direct investment, ARDL, panel, recurrent and capital

\section{Background to the Study}

The global drive towards devolution was justified on the resources of sub national which was expected to deliver much better efficiency in different public sectors and the direct investment growth held by direct investment (Martinez Vasquez \& McNab, 2005; Ezcurra \& Rodríguez-Pose, 2010; IMF, 2016). Further, lots of study on expenditure and economic growth, by direct investment growth have been conducted at the national and international level, for example, Lin and Liu (2000); and Kimaro et al. (2017). However, County government area is a fertile ground for research, but has not garnered the attention national government has. Since counties are major service providers, changing their structure may have a considerable effect on various aspect of its governance such as policy decisions, expenditure levels, and service delivery among others (Mitchell, 2005; Morgan, 2006; Chebet, 2013).

The mechanisms through which fiscal decentralization may affect growth are as follows. First, government investment in infrastructure is believed to have a direct effect on economic growth by direct investment through increasing the economy's capital stock. The second channel is the externality effect of government spending that alters economic growth, investment growth, foreign reserve, direct investment and by raising production through expenditure on growth of nations, which contribute to the accumulation of human capital. The third channel is expenditure on goods and services that increases the aggregate demand in the economy (Abu \& Abdullahi, 2010; Kakar, 2011). The fourth channel is intersectoral productivity differentials which makes some sectors to be more productive than others (Agenor, 2007; Maingi, 2017).

Table 1 below shows the trend of African countries's GCP per capita by selected county, 2013-2017 as provided by Gross County Product (GCP) report 2019, increasing (KNBS, 2019). 
Table 1. National Per capita GCP and selected county share of GCP

\begin{tabular}{cccccccc}
\hline Year & African countries & Nairobi & Mombasa & Kiambu & Mandera & West Pokot & Turkana \\
\hline $\mathbf{2 0 1 3}$ & $\mathbf{8 7 2 6 1}$ & 212543 & 150156 & 98566 & 25867 & 36077 & 37753 \\
$\mathbf{2 0 1 4}$ & $\mathbf{8 9 4 3 0}$ & 208509 & 152625 & 102992 & 26594 & 36926 & 38277 \\
$\mathbf{2 0 1 5}$ & $\mathbf{9 1 9 8 9}$ & 208733 & 153030 & 109361 & 27287 & 38111 & 39982 \\
$\mathbf{2 0 1 6}$ & $\mathbf{9 4 7 8 9}$ & 211055 & 159418 & 114762 & 27968 & 39493 & 39699 \\
$\mathbf{2 0 1 7}$ & $\mathbf{9 6 8 0 0}$ & 212498 & 168448 & 118343 & 28602 & 38021 & 38592 \\
\% GCP for 2013-2017 & $\mathbf{5 . 5}$ & 21.7 & 4.7 & 5.5 & 0.5 & 0.7 & 1.1 \\
\hline
\end{tabular}

Source: Bundervoet et al. (2015); GoK (2018); KNBS (2019).

Table 1 above shows that Nairobi resident are the richest in the African countries with each spending over sh 200,000 per year, above national GCP per capital of sh 96,800. Mombasa has a GCP per capita of slightly above sh 150,000, followed by Kiambu at just above sh 100,000 GCP per capita. Mandera, West Pokot and Turkana are poorest counties with resident spending less than sh 50,000 per year. Nairobi contributes the most of African countries's GCP at 21.7 percent followed by Nakuru at 6.1 per cent. Only a quarter of the counties are above the national GCP per capita, highlighting huge disparities across counties in terms of GCP per capita (Bundervoet et al., 2015; KNBS, 2019).

Table 2. Government size in African countries

\begin{tabular}{llcccccc}
\hline YEAR & & $\mathbf{2 0 1 2}$ & $\mathbf{2 0 1 3}$ & $\mathbf{2 0 1 4}$ & $\mathbf{2 0 1 5}$ & $\mathbf{2 0 1 6}$ & $\mathbf{2 0 1 7}$ \\
\hline Real GCP growth rate & $-\quad(\%)$ & 4.6 & 5.9 & 5.4 & 5.7 & 5.9 & 4.9 \\
National Expenditure - & $(\boldsymbol{\%}$ GCP) & 23.7 & 23.7 & 25.9 & 26.6 & 25.3 & 24.6 \\
County Expenditure & $-\quad(\%$ GCP) & 1.0 & 4.3 & 5.4 & 5.4 & 5.3 & 5.3 \\
\hline
\end{tabular}

Source: KIPPRA (2016); GoK (2018); KNBS (2019). The trend between government size and GDP growth.

\section{Theoretical Literature}

According Harrod (1973); and Romer (2001), Harrod-Domar (H-D), model have determined in Keynesian framework of growth in the economy. H-D pointed out that, the warranted rate could be influenced by three different components of effective demand coming from the government sector, the private sector, in the form of autonomous investment, and the foreign sector. Further, Harrod (1973) argued that fiscal policy was appropriate to achieve this long-term objective. It should be used by varying the tax rates while keeping government expenditure constant. Monetary policy was appropriate instead to deal with what H-D defined as the short-term policy objective of correcting the divergence of the actual rate from the warranted rate and stabilizing the fluctuations of the economy (Harrod, 1973; Romer, 2001). The model stresses the dual role of capital (Romer, 2001). The model description are fixed and ratio to assumed to be fixed in case of developing countries economic growth. (Mendoza et al., 1997; Branson, 2002; Ntibagirirwa, 2014).

The condition of coffecient is relaxed by neo-classical growth model (Harrod, 1973; Mendoza et al., 1997). These refinements allow increasing capital intensity to be distinguished from technological progress. The investment and growth are determine the countries growth by different regions and having a saving investment rate. And the growth of countries accumulation more capital work in per-capita. Solow (1956). The specific model prescription determined the long run growth of individual state. (Mankiw et al., 1992; Mendoza et al., 1997; Romer, 2001).

The prior research has introduced different modifications to the neoclassical Solow model aiming at highlighting the role of a factor(s) in explaining economic growth by foreign direct investment. Mankiw et al. (1992) emphasizes the importance of adding human capital to the Solow model. Islam (1995) examines the results of the augmented Solow model obtained by MRW using cross-section regressions change by using different techniques, namely panel data. Ram (1986); and Barro (1990), in turn, allows for the government expenditure to affect the production function. Barro (1990) model constitutes without any doubt a breaking point in this evolution. By allowing for government spending, that is capital expenditure that increases private capital marginal productivity, as for example infrastructure sector or property rights in counties.

The Ramsey-Cass Koopmans (RCK) model is similar to the Solow model; however, savings in the RCK model is endogenous, as opposed to exogenous as in the Solow model (1956). The RCK model builds upon the Solow model by incorporating government spending and household optimization through consumption and risk. Both of these models have the same implications once in the steady state: the growth rates of output, capital, savings, and consumption, all in per worker terms, grow at the rate of technological progress (Romer, 2001). 
The theory of Keynes's (1936) determined the expenditure and increase economic growth by advance GCP and multiplier effects in economic growth (Branson, 2002). According to this theory African states conclude the expenditure of economic growth in investment (Maingi, 2017).

\subsection{Empirical Studies}

Gebreegziabher (2018) determined the effects of fiscal policy particularly expenditure of state and taxation on economic growth by investment growth by foreign reserve by investment growth by foreign reserve in Africa from 1966-2014, using the time series ARDL modeling approach. On the fiscal side, a good performance in the collection of indirect tax revenue and increased capital and recurrent expenditure had a significant positive effect on the growth of the economy both in the short-run and long-run. This study ignored causality tests during the analysis.

Oguso (2017) did a study on effects of public expenditure in African countries' economic growth by foreign direct investment. The study used sector level macro panel data from fiscal year 1999 to 2015, with a cross-sectional unit of seven sectors using panel ARDL model. The findings showed that an increase in share of public recurrent costs in sectoral GDP has an insignificant negative effect on sectoral growth in the short-run but a significant negative effect in the long-run. The results also showed that an increase in share of sectoral capital expenditure has a positive but insignificant effect in the short-run but a significant growth effect in the long-run.

Gisore (2017) examined empirically how components of public sector size relate to GDP growth in East Africa from 1985-2015, using panel fixed effect model. The finding confirm the conventional view that relative capital spending - advances economic growth by direct investment growth by direct investment growth by direct investment growth while consumption expenditure retards it. Finally, human capital allocation was insignificant, probably because effects from education sector would have very long lags. This study ignored co integration test to test for long-run relationship between underlying variables change.

Maingi (2017) conducted descriptive study on expenditure of states in direct investment Ram (1986) model. According to this study the endogenous growth theory for the period 1963 to 2008.The strength for this study was that it was able to compare the properties of the different components of public expenditure using VAR.

\section{Methodology}

\subsection{Research Design}

This study employed historical research design so as to capture the trend of county growth and expenditure. The research period has taken between 2013-2017 with annual serious data in 47 countries and ARDL research technique compute the observation in panel data. The secondary data has been taken from the World Bank side and each country its own semi-autonomous government structure so the study utilized the direct investmentin review reports.

\subsection{Model Specification}

The research model specified regression by $\log$

$$
\begin{gathered}
y=f(r g, c g, n g, a r, h c, c r, t c, e c) \\
\operatorname{lny}_{i, t}=\beta_{0}+\beta_{1} \operatorname{lnrg}_{i, t-1}+\beta_{2} \operatorname{lncg}_{i, t-1}+\beta_{3} \operatorname{lnng}_{i, t-1}+\beta_{4} \operatorname{lnar}_{i, t-1}+\beta_{5} \operatorname{lnh}_{i, t-1}+\beta_{6} \operatorname{lncr}_{i, t-1}+ \\
\beta_{7} \operatorname{lnt} c_{i, t-1}+\beta_{8} \operatorname{lnec}_{i, t-1}+\varepsilon_{i, t}
\end{gathered}
$$

Where,

ln y -County real Gross County Product (GCP) per Capita (Proxy for economic growth by direct investment growth by direct investment growth), lncg - County government capital expenditure, ln rg - County government recurrent expenditure, In ar - Absorption rate of County government expenditure, In hc -County Human capital, ln cr - County Corruption rate, ln tc - County Total Crime rate, ln ec -Electricity Consumption.

\subsection{Panel Unit Root Test}

In the panel unit root individually elaborated each variable with in non-stationary and resolve by Levin-Lin-Chu (LLC), Harris-Tzavalis (HT) and Phillips - Perron (PP) test individual. The serious of unit root The study adopted by HT techniques for non-stationary variables and the unit root considering equation are stated below.

$$
\begin{gathered}
\Delta X_{i, t}=\alpha_{i}+\beta_{i} X_{i, t-1}+\sum_{j=1}^{k} \gamma_{i, j} \Delta X_{i, t-j}+\varepsilon_{i, t} \\
\Delta \operatorname{lny}_{i, t}=\beta_{0}+\sum_{i=0}^{k} \beta_{1} \Delta \operatorname{lng}_{i, t-1}+\sum_{i=0}^{k} \beta_{2} \Delta \operatorname{lncg}_{i, t-1}+\sum_{i=0}^{k} \beta_{3} \Delta \operatorname{lnng}_{i, t-1}+\sum_{i=0}^{k} \beta_{4} \Delta \operatorname{lnar}_{i, t-1}+ \\
\sum_{i=0}^{k} \beta_{5} \Delta \operatorname{lnh}_{i, t-1}+\sum_{i=0}^{k} \beta_{6} \Delta \operatorname{lncr}_{i, t-1} \sum_{i=0}^{k} \beta_{7} \Delta \operatorname{lnec}_{i, t-1}+\sum_{i=0}^{k} \beta_{8} \Delta \operatorname{lntc}_{i, t-1}+\gamma E C M_{i, t-1}+\varepsilon_{i, t}
\end{gathered}
$$


In this model $\gamma_{t}$ is the impact multiplier or short-run effect that measures the immediate impact that a change in $G_{t}$ will have on change in $Y_{t .}$ On the other hand, $E C M_{t-1}$ is the feedback effect or adjustment effect. The difference $X_{i, t}$ is dependent variable, $\varepsilon_{i, t}$ is the white-noise disturbance with a variance $\sigma^{2}$ of $, 1, \ldots, \mathrm{N}$ indexes county and $1, \ldots, \mathrm{T}$ indexes time and ECM indicated supported variable.

\subsection{Post Estimation Panel Diagnostic Tests}

The estimation results are biased, inconsistent and inefficient if econometric problems such as heteroscedasticity, serial correlation, model mis-specification and correlation of error term occur in the model. Therefore, diagnostic checking was essential to ensure the model was free from econometric problems.

\section{Results and Discussions}

\subsection{Descriptive Statistics of GCP per Capita and Growth Variables}

Descriptive statistics of real Gross County Product (GCP) per capita and independent variables were used to describe the trends of the variables under study. Table 3 elaborated the descriptive techniques.

Table 3. Descriptive statistics results of GCP and growth variables

\begin{tabular}{ccccccc}
\hline Variable & Mean & Standard Deviation & Min & Max & Skewness & Kurtosis \\
\hline $\ln y$ & 4.805 & 0.172 & 4.413 & 5.327 & 0.604 & 0.563 \\
$\ln \mathrm{cg}$ & 2.647 & 1.090 & -0.658 & 3.806 & -1.595 & 1.323 \\
$\ln \mathrm{rg}$ & 3.275 & 0.532 & 1.288 & 4.324 & -1.234 & 0.970 \\
\hline
\end{tabular}

Note. all the absolute values of the variables are expressed in natural $\log (\ln )$ model so as to allow for regression coefficients to be treated as elasticities.

ln y -County real Gross County Product (GCP) per Capita (Proxy for economic growth by direct investment growth), ln cg - County government capital expenditure, ln rg- County government recurrent expenditure.

The descriptive findings, from Table 3 above, were that capital and recurrent county expenditure have relatively larger variation compared to the other variables in the regression model. For example, the capital expenditure ranges between -0.658 and 3.806, while recurrent expenditure ranges between 1.288 and 4.324. This suggests that capital and recurrent spending have higher variation compared to other variables in this study. This may indicate that capital and recurrent expenditure may be volatile. Because they are determined by the expenditure allocation as determined by fiscal transfers and grants from the national government to finance their budgets, county budget allocation and steady use of funds, and tax revenue and distribution across counties. Further, The county expenditure shows expenditure which compared to the recurrent expenditure. Usually, there is always a lag between capital spending, budgeting and disbursement (IMF, 2016; OCOB, 2019).

\subsection{Correlation Matrix of GCP Per Capita and Growth Variables}

In this study, Pearson Correlation (r), the most commonly used bivariate correlation technique, was used in variables. The correlation matrix results are shown in Table 4 below.

Table 4. Correlation matrix results

\begin{tabular}{|c|c|c|c|}
\hline & $\ln y$ & $\ln c g$ & $\ln r g$ \\
\hline $\ln y$ & 1 & & \\
\hline P-value & - & & \\
\hline $\ln c g$ & 0.035 & 1 & \\
\hline P-value & 0.5890 & - & \\
\hline $\ln r g$ & $0.248 * * *$ & $0.819 * * *$ & 1 \\
\hline P-value & 0.0001 & 0.0000 & - \\
\hline
\end{tabular}

Note. $* * *$ Significant at 1 percent, $* *$ significant at 5 percent and * Significant at 10 percent using two tail test.

The correlation coefficient between county economic growth by investment growth by foreign reserve. This shows that government recurrent expenditure can contribute positively to economic growth by investment growth by foreign reserve by investment growth by foreign reserve by improving purchasing power. Further, from the results the relationship between capital expenditure and coefficient of county was insignificant at 5 percent level. Most often, the actual capital amount disbursed relative to recurrent expenditure is very small and may not have been enough to have a significant and expected positive effect on GCP growth (OCOB, 2018). Further, most of the variables exhibited a value less than 0.5 correlation index which implies a low likelihood of 
the problem of multicollinearity in the data used.

\subsubsection{Panel Unit Root Tests}

The table-5 indicated by HT (1999) unit root test, while doing the HT test, the study picked the lag length on the augmentation term based on whether the exclusion of lagged term causes serial correlation in the test equation's error term.

Table 5. Results of HT

\begin{tabular}{ccccccccc}
\hline Variable & Statistic & $\mathbf{Z}$ & P-Value & Variable & Statistic & $\mathbf{Z}$ & P-Value & Order of Integration \\
\hline $\ln y$ & 0.5352 & 0.495 & 0.6896 & $\Delta \ln y$ & -0.6761 & $-12.758^{* * *}$ & 0.0000 & $\mathrm{I}(1)$ \\
$\ln c g$ & 0.1754 & $-4.568^{* * *}$ & 0.0000 & & & & $\mathrm{I}(0)$ \\
$\ln r g$ & 0.1627 & $-4.745^{* * *}$ & 0.0000 & & & & & $\mathrm{I}(0)$ \\
\hline
\end{tabular}

Note. The null hypothesis is that the series is non stationary or the series has a unit root. $* * * 1 \%$ significance level, and $* * 5 \%$ significance level, $\Delta$ Symbol indicates that the first difference of the variable was taken.

The results of Table 5 indicate the level of GCP with 5 percent so therefore the null hypothesis for all can not be rejected in first difference.

\subsubsection{Co-Integration Test}

The co-integration test based on autoregressive distributed lag model (ARDL) approach introduced in Pesaran et al. (2001). ARDL bounds testing approach has advantage over the other cointegration technique, such as: Engle and Granger (1987), Johansen-Juselius (1990), Johansen (1992), and Saikkonen and Lutkepohl (2000). ARDL bounds testing approach has an advantage as it is applicable regardless the stationary properties of each independent variable (Narayan \& Smyth, 2005). The approach have been determined by 30 to 80 oberservation in sample size with $\mathrm{F}$ bound investigation.

Table 6. F-Bounds test result for panel co integration relationship

\begin{tabular}{lccccc}
\hline Test Statistics & Value & Lag & Significance Level & \multicolumn{2}{c}{ Bounds Critical values } \\
\hline F-Statistics & $6.261707^{* *}$ & 4 & & $\mathrm{I}(0)$ & $\mathrm{I}(1)$ \\
& & & $1 \%$ & 2.79 & 4.10 \\
& \multirow{2}{*}{8} & & $5 \%$ & 2.22 & 3.39 \\
K & & $10 \%$ & 1.95 & 3.06 \\
\hline
\end{tabular}

Note. Null hypothesis: No level relationship, $* * * 1 \%$ significance level, and ${ }^{* *} 5 \%$ significance level.

The lag length 4 was selected based on the AIC. Critical values were obtained from Narayan (2004) case II, restricted trend intercept and no trend for 47 observations, pp 26-28. The number of regressors is 8 .

Table 6 indicated 6.26 value which is higher from the significant level in long run relationship in regressor panel data.

\subsection{Long-Run Effect of Government Recurrent Expenditure on Economic Growth by Direct Investment Growth}

The Government expenditure ( $\mathrm{Rg})$ indicated in Table 7 presents with recurrent on county economic growth by direct investment growth in the long-run.

Table 7. Long-run regression result based on AIC-ARDL $(0,1,0,3,1,1,1)$

\begin{tabular}{ccccc}
\hline Variable & Coefficient & Standard error & t- Statistics & P-value \\
\hline $\ln r g$ & $0.172109^{* *}$ & 0.074648 & 2.305608 & 0.0221 \\
$\ln c g$ & 0.039798 & 0.044916 & 0.886040 & 0.3766 \\
$\ln a r$ & $0.737254^{* * *}$ & 0.357025 & 2.064994 & 0.0401 \\
$\ln c r$ & $0.326320^{* * *}$ & 0.083228 & 3.920807 & 0.0001 \\
$\ln e c$ & $0.217309^{* * *}$ & 0.050008 & 4.345518 & 0.0000 \\
$\ln h c$ & 0.069975 & 0.167153 & 0.418631 & 0.6759 \\
$\ln t c$ & $-0.203137^{*}$ & 0.113608 & -1.788058 & 0.0752 \\
Cons & 0.298654 & 0.190859 & 1.564786 & 0.1191 \\
\hline
\end{tabular}

Note. $* * *$ denotes significant at 1 percent, $* *$ significant at 5 percent, $*$ significant at 10 percent.

In y -County real Gross County Product (GCP) per Capita (Proxy for economic growth by direct investment growth by direct investment growth), ln cg - County government capital expenditure, ln rg- County government recurrent expenditure.The goodness of fit is 0.836 with F-test $(4,210)$ in $5 \%$. 
The growth by direct investmentwas computed by ARDL in positive and statistically significant in long-run. Since the result is significant at 5 percent level of significance, null hypothesis was rejected at 5 percent level of significance.

The $0.17 \%$ result has been computed on the productive recurrent expenditure with capital expenditure in long run. The lots of countries promoted education, health with pre-primary service and significant spending like health and education. The $62.0 \%$ in development spending and 38\% in OCBS, 2015. The table-7 indicated capital expenditure on GDP in 47 countries with recurrent expenditure like health and education sector. The estimated coefficient is $65 \%$ spending rate of direct investment by direct investmentand economy expands in long run. The effect of economy investigates by growth in long run. Other side the corruption perception rate has significant effected by negatively in economic growth rate and the survey report ranked corruption is the third major problem in economy and it create the negative impact in African countries.

The coefficient of determination (adjusted $\mathrm{R}^{2}$ ) test was used to show the total variation of the dependent variable that can be explained by the independent variable. The adjusted $\mathrm{R}^{2}$ was 0.86 , which implied that 86 percent of the variations in the dependent variable (real GCP) are explained by the changes in explanatory variables in the model within the period under review, which demonstrates that the regression model has a fairly good fit since it explains the largest variation of the dependent variable. The joint effect of these components of county expenditure and control variables on county economic growth by direct investment growth is statistically significant as indicated by the computed F-Statistic and its probability. Different post estimation panel diagnostic tests were carried out. The study used Breusch-Godfrey serial correlation LM test in panel data. From Table 7 result, the p-value was greater than $0.05(0.4861)$, the study failed to reject the null hypothesis and concluded that the data did not have first-order autocorrelation. Breusch-Pagan test was carried out to test for heteroskedasticity, from above result the p-value was below $0.05(0.000)$ and as such it was significant hence revealing that heteroscedasticity was a problem in the model. This study used panel robust standard error to correct it. Contemporaneous correlation was tested using Pesaran CD test of independence. The p-value was greater than $0.05(0.1967)$ and therefore not significant at 5 percent level of significance. From the result contemporaneous correlation was not a problem, since 0.4165 was above the $\mathrm{P}$ value 0.05 , Ramsey reset result showed that the model was well specified and did not suffer from omitted variable at 5 percent significance level, this study failed to reject the null hypothesis of correct specification. This indicated that the functional form was correct.

\subsection{Recurrent Expenditure by Short-Run}

In the panel data the ARDL long-run co-integrating model has been estimated, the next step is to model the short-run dynamic parameters within the panel ARDL framework. the estimated short-run regression results revealed similar results, as presented in Table 8 below.

Table 8. Short-run regression

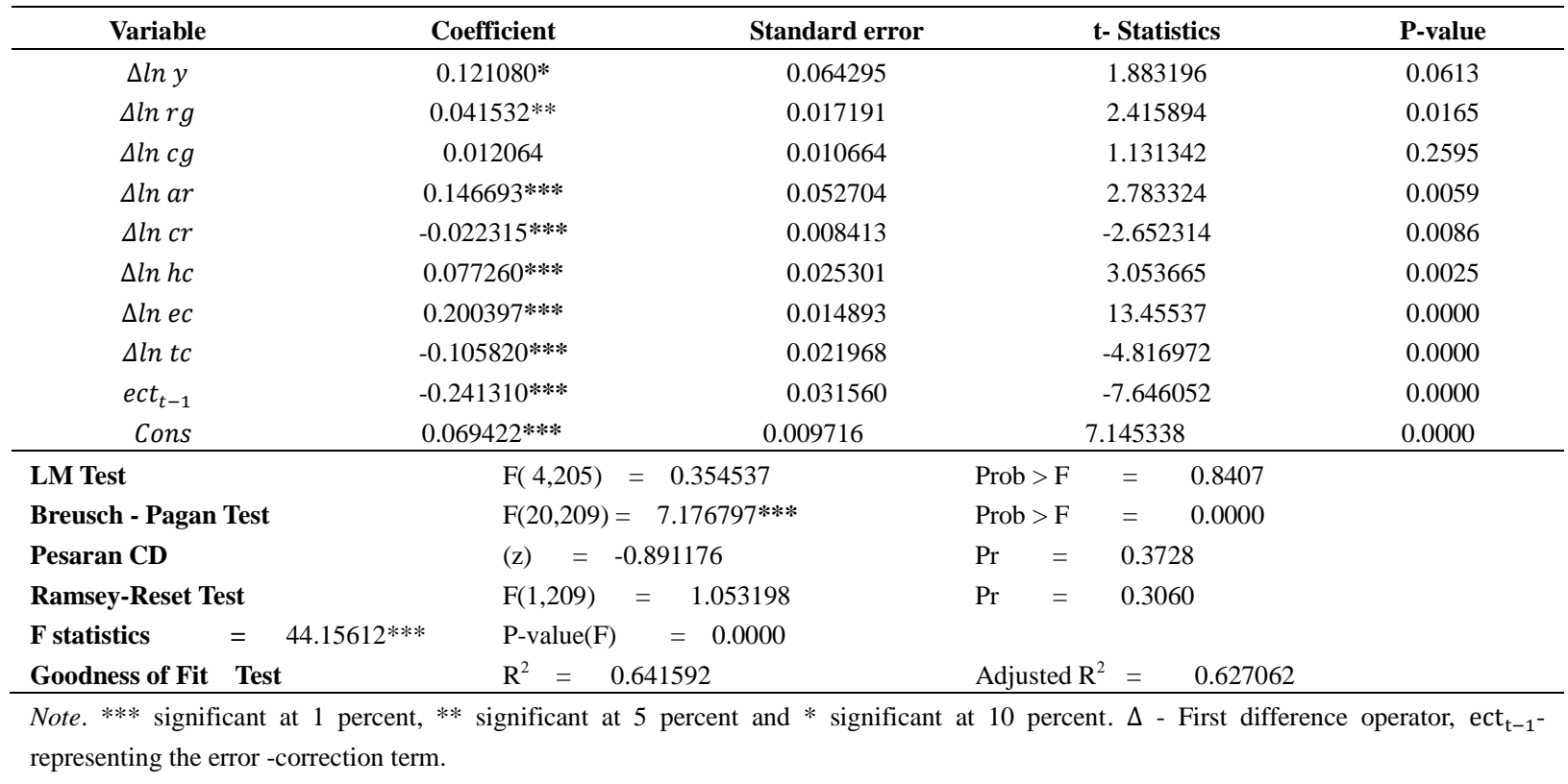


Table 8 indicates the LM test 0.354 with different coefficient error and t-statistics and adjusted R square is 0.62 in 47 countries in the short-run which is not categorized and not provided the high recurrent allocation in weak infrastructure. The capital expenditure on real GDP was insignificant in short-run and it take effect on economy by the actual capital. Also the expected positive impact on growth significantly affected on actual capital in African countries.

This result can increase, leading to increases in productivity for private factors of production and the accumulation of physical and human capital (skilled), thus economic growth by investment growth by foreign reserve by investment growth by foreign reserve (Fournier \& Johansson, 2016; OCOB, 2019). In addition, the government of African countries offers secondary education to population at no cost or at subsidized level.

The direct investmentindicated in investment crises in public and private sector by short and long run effects. (Cardenas, 2007; McCollister et al., 2010), whereas other concludes that the effect is insignificant (Goulas \& Zervoyianni, 2012; Ray \& Ishita, 2009).

\section{Conclusion and Recommendations}

\subsection{Conclusion}

The computed results indicated the empirically effect on recurrent expenditure on GDP of the countries. The individual ARDL shows the effects of countries recurrent spending economic growth by foreign direct investment. The short and long run techniquesregressor results stimulate an increased output depending on expenditure multipliers. The country government stimulated spending through increasing purchasing power, which stimulated creates new jobs with relationship of expenditure budget allocation. The methodology revealed the capital expenditure which was insignificant both in long-run and short-run with addition on recurrent expenditure. The lacks of prioritization of government projects the quality of capital expenditure in financial planning process and investigate a longer period of control variable. The absorption rate of human capital and elasticity consumption as a key determinant of growth where the factor indicate economic growth by foreign direct investment.

\subsection{Recommendations and Implications}

The recommendation refers that robust growth of nationin direct investmentand its necessary an increased output on expenditure from past imperial results. The direct investmentenhance growth by policy makers and is to examine on average $63 \%$ country budget.

\section{References}

Abu, N., \& Abdullahi, U. (2010). Government Expenditure and Economic Growth in Nigeria, 1970-2008: A Disaggregated Analysis. Business and Economic Journal, 4(1), 1-11.

Adawo, M. A. (2011). Has education (human capital) contributed to the economic growth of Nigeria? Journal of Economic and International Finance, 3, 46-58.

African countries National Bureau of Statistics (KNBS). (2019). Gross County Product Report 2019, Nairobi.

African countries Open Data Project. (2012). Map showing Counties under the new African countriesn constitution. Retrieved from https://opendata.go.ke/facet/counties

Afzal, M., Farooq, M. S., Ahmad, H. K., Begum, I., \& Quddus, M. A. (2010). Relationship between school education and economic growth in Pakistan: ARDL bounds testing approach to co integration. Pakistan Economic and Social Review, 48, 39-60.

Agbonkhese, A., \& Asekome, M. (2014). Impact of Public Expenditure on the Growth of Nigerian Economy. European Scientific Journal, 10(28), 219-229.

Age'nor, P. (2007). Economic Adjustment and Growth. New Delhi: Viva books Private Limited.

Akpan, N. (2013). The Impact of Public Sector Spending on Economic Growth of Nigeria. Journal of Economic and Sustainable Development, 5(3), 216-224.

Baltagi, B. H. (2008). Econometric Analysis of Panel Data (4th ed.). New York, John Wiley Ltd.

Barro, R. (1990). Government Spending in a Simple Model of Endogenous Growth. The Journal of Political Economy, 98(5), 103-125. https://doi.org/10.1086/261726

Barro, R., \& Sala-i, M. X. (2003). Economic Growth (2nd ed.). Cambridge, MIT press.

Bastagli, F., Coady, D., \& Gupta, S. (2012). Income inequality and fiscal policy. International Monetary Fund, No. 12/08R. https://doi.org/10.5089/9781475510850.006 
Bayer, Y. (2014). Electricity Consumption and Economic Growth in Emerging Economies. Journal of Knowledge Management, Economic and Information Technology, 4(2),1-18.

Becker, S. O., Egger, P. H., \& von Ehrlich, M. (2012). Too Much of a Good Thing? On the Growth Effects of the EU's Regional Policy. European Economic Review, 56, 648-668. https://doi.org/10.1016/j.euroecorev.2012.03.001

Bhatia, H. (2002). Public Finance (25th ed.). New Delhi, Vikas Publishing House.

Branson, H. (2002). Macroeconomic Theory and Policy (2nd ed.). Delhi, Nice Printer.

Brown, V., \& Jackson, M. (1996). Public Sector Economic. London, Blackwell Publisher.

Bundervoet, T., Maiyo, L., \& Sanghi, A. (2015). Measuring National and Sub national Economic Growth in Africa from Outer Space, with an Application to African countries and Rwanda. World Bank Policy Research Working Paper, No 22922. The World Bank. https://doi.org/10.1596/1813-9450-7461

Cárdenas, M. (2007). Economic Growth in Colombia: A Reversal of 'fortune'? Working papers series Documentos de trabajo, 1-36.

Choe, C., Dzhumashev, R., Islam, A., \& Khan, Z. H. (2013). The Effect of Informal Networks on Corruption in Education: Evidence from the Household Survey Data in Bangladesh. The Journal of Development Studies, 49(2), 238-250. https://doi.org/10.1080/00220388.2012.709620

Claudia, A., \& Goyeau, D. (2013). EU Funds Absorption Rate and the Economic Growth. Timisoara Journal of Economic and Business, 6(20), 153-170.

Cohen, D., \& Soto, M. (2007). Growth and Human capital: Good data, good results. Journal of Economic Growth, 1(3), 113-207. https://doi.org/10.1007/s10887-007-9011-5

EACC. (2017). National Ethics and Corruption Survey. EACC Research Report, 3, 2017.

Engle, R. F., \& Granger, C. W. J. (1987). Cointegration and error correction representation: Estimation and testing. Econometrica, 55, 251-276. https://doi.org/10.2307/1913236

Ezcurra, R., \& Rodríguez-Pose, A. (2010). Is Fiscal Decentralization Harmful for Economic Growth? Evidence from the OECD Countries. SERC Discussion Paper, UK. https://doi.org/10.1093/jeg/lbq025

Facchini, F., \& Melki, M. (2013). Efficient Government Size in France. European Journal of Political Economy, 31, 1-14. https://doi.org/10.1016/j.ejpoleco.2013.03.002

Folster, S., \& Henrekson, M. (2001). Growth effects of government expenditure and taxation in rich countries. European Economic Review, 45(8), 1501-1520. https://doi.org/10.1016/S0014-2921(00)00083-0

Fournier, J. M., \& Johansson, A. (2016). The effect of the size and the mix of public spending on growth and inequality. OECD Library. Economic department working paper, 1344.

Gebreegziabher, S. (2018). Effects of Tax and Government Expenditure on Economic growth by direct investment growth by direct investment Growth in Ethiopia. In A. Heshmati, \& H. Yoon (Eds.), Economic Growth and Development in Ethiopia. https://doi.org/10.1007/978-981-10-8126-2_5

Gebrehiwot, G. K. (2015). The Impact of Human Capital Development on Economic Growth in Ethiopia: Evidence from ARDL Approach to Co integration. Journal of Economic and Sustainable Development, 6(13), 155-168.

Gisore, N. (2017). Public Sector Size and GDP Growth Nexus. Quarterly Journal of Econometrics Research, 3(1), 1-11. https://doi.org/10.18488/journal.88.2017.31.1.11

GOK (Government of African countries). (2004 - 2018). Economic surveys. Nairobi, African countries National Bureau of Statistics.

Granger, C. W. (1988). Causality, Cointegration and Control. Journal of Economic Dynamics and Control, 12, 551-559. https://doi.org/10.1016/0165-1889(88)90055-3

Greene, W. H. (2012). Econometric Analysis (7th ed.). England, Pearson Education Limited.

Gujarati, D. (2004). Basic Econometrics (4th ed.). McGraw Hill Education, London.

Gupta, R. (2018). The impact of government expenditure on economic growth in Nepal. Quest International College, Pokhara University, Nepal. Accessed on 7/8/2018. https://doi.org/10.2139/ssrn.3099218

Hammed, A. (2016). Economic Growth Effects of Public Capital Expenditures: Evidence from South Africa's 
Municipalities. Financial Fiscal Commission Report, 38-58.

Hanousek, J., \& Kočenda, E. (2011). Public investments and fiscal performance in new EU member states. Fiscal Studies, 32(1), 43-72. https://doi.org/10.1111/j.1475-5890.2011.00127.x

Harris, R. D., \& Tzavalis, E. (1999). Inference for unit roots in dynamic panels where the time dimension is fixed. Journal of Econometrics, 91, 201-226. https://doi.org/10.1016/S0304-4076(98)00076-1

Harrod, R.F. (1973). Economic Dynamics. London: Macmillan. https://doi.org/10.1007/978-1-349-01696-9

Hassler, U., \& Wolter, J. (2006). Autoregressive distributed lag models and cointegration. AStA Advances in Statistical Analysis, 90(1), 59-74. https://doi.org/10.1007/s10182-006-0221-5

Heckelman, J. C., \& Powell, B. (2010). Corruption and the institutional environment for growth. Comparative Economic Studies, 52(3), 351-378. https://doi.org/10.1057/ces.2010.14

Husnain, M. I. (2011). Is the Size of Government Optimal in Pakistan: A Time Series Analysis, 1975-2008. Journal of Economic \& Economic Education Research, 12(2).

Husnain, M. I., Khan, M., Haq Padda, I., Akram, N., \& Haider, A. (2011). Public Spending, FDI and Economic Growth: A Time Series Analysis for Pakistan (1975-2008). International Research Journal of Finance and Economic, 61, 21-27.

ICPAK. (2014). Paper on the impact of Decentralized Funds in African countries. ICPAK Paper18, Nairobi.

Iftikhar, M. (2011). Is the Size of Government Optimal in Pakistan: A Time Series Analysis? 1975-2008. Journal of Economic Education Research, 12(2), 41-49.

IMF. (2000-2017). Regional economic outlook, Sub-Saharan Africa. Washington, D.C.

Ionica, O., Andreea, M., Gabriela, P., \& Raluca, B. (2017). The Effects of the Structural Funds on the Romanian Economic Growth. Economic, 13(2), 91-101.

Ivanov, V., \& Lutz, K. (2005). A Practitioner's Guide to Lag Order Selection for VAR Impulse Response Analysis. Studies in Nonlinear Dynamics and Econometrics, 9(1), 1-36. https://doi.org/10.2202/1558-3708.1219

Javid, A. Y., Javid, M., \& Awan, Z. A. (2013). Electricity consumption and economic growth: Evidence from Pakistan.Economic and Business Letters, 2(1), 21-32. https://doi.org/10.17811/ebl.2.1.2013.21-32

Kimaro, E. L., Chee, C. K., \& Lin, L. S. (2017). Government Expenditure, Efficiency and Economic Growth: A Panel Analysis of Sub Saharan African Low Income Countries. African Journal of Economic Review, 5(2), 34-54.

KIPPRA. (2016). African countries Economic Report: Fiscal Decentralization in Support of Devolution Nairobi. Kippra.

Lin, S. Y., \& Liu, Z. (2000). Fiscal Decentralization and Economic Growth in China. Economic Development and Cultural Change, 49, 1-21. https://doi.org/10.1086/452488

M'amanja, D., \& Morrissey, O. (2005). Fiscal Policy and Economic Growth in African countries. Credit Research papers, No. 05/06. United Kingdom.

Maingi, J. N. (2017). The Impact of Government Expenditure on Economic Growth in African countries: 1963-2008. Advances in Economic and Business, 5(12), 635-662. https://doi.org/10.13189/aeb.2017.051201

Mankiw, G., Romer, D., \& Weil, D. (MRW). (1992). A contribution to the empirics of economic. Quarterly Journal of Economic, CVII(2), 407-437. https://doi.org/10.2307/2118477

Martinez-Vazquez, J., \& McNab, R. (2005). Fiscal Decentralization, Macro - stability and Growth. International Studies Working Paper No. 0506, Georgia State University.

McCollister, K. E., French, M. T., \& Fang, H. (2010). The cost of crime to society: New Crime-Specific Estimates for Policy, 108(1), 98-109. https://doi.org/10.1016/j.drugalcdep.2009.12.002

McCreadie, K. (2009). Adam Smith's The Wealth of Nations: A Modern-day Interpretation of a Classic. Infinite Idea, Oxford.

Mitchell, D. (2005). The Impact of Government Spending on Economic Growth. Washington DC, Heritage Foundation.

Mo, P. (2001). Corruption and Economic growth. Journal of Comparative Economic, 29, 66-79. 
https://doi.org/10.1006/jcec.2000.1703

Mudaki, J., \& Masaviru, W. (2012). Does the composition of public expenditure matter to economic growth for African countries? Journal of Economic Growth by Direct Investments and Sustainable Development, 3(3), 60-70.

Muguro, W. J. (2017). Effect of Public Expenditure on Economic Growth in African countries: 1963-2015. Master's thesis, KCA University, Nairobi, African countries.

Muigai, M. N. (2015). The impact of government expenditure on gross domestic prod. University of Nairobi, Nairobi.

Muriu, A. (2013). Decentralization, citizen participation and local public service; A study on the nature and influence of citizen participation on decentralized service delivery in African countries. Master's thesis, University of Potsdam, Berlin, Germany.

Musgrave, R. (1969). Fiscal Systems. London, Yale University Press.

Muthui, J., Kosimbei, G., Maingi, J., \& Thuku, G. (2013). The Impact of Public Expenditure Components on Economic growth by direct investment growth by direct investment Growth in African countries 1964-2011. International Journal of Business and Social Science, 4, 233-252.

Mutie, N. (2014). Effects of Devolved Funds on Economic Growth in African countries: Empirical Investigation (1993-2012). Master's thesis, University of Nairobi, Nairobi.

Nanjala, C. S. (2015). Explaining the Relationship between Public Expenditure and Economic Growth in African countries using Vector Error Correction Model (VECM). International Journal of Economic Sciences, 4(3), 19-38. https://doi.org/10.20472/ES.2015.4.3.002

Narayan, P. K. (2004). Reformulating critical values for the bounds $F$-statistics approach to cointegration: An application to the tourism demand model for Fiji. Department of Economic, Discussion Papers No. 02/04, Monash University, Melbourne, Australia.

Narayan, P. K., \& Smyth, R. (2005). The residential demand for electricity in Australia: An application of the bounds testing approach to cointegration. Energy Policy, 33, 457-464. https://doi.org/10.1016/j.enpol.2003.08.011

Ntibagirirwa, S. (2014). Philosophical Premises for African Economic Development Sen' Capability Approach. Globethics net Theses, 7, Geneva.

OCOB (Office of the Controller of Budget). (2013-2018). Annual County Governments Budget Implementation Review Report. Nairobi, Government Printer.

Odhiambo, N. M. (2015). Government Expenditure and Economic Growth in South Africa: an Empirical Investigation. Atlantic Economic Journal, 43(15), 393-406. https://doi.org/10.1007/s11293-015-9466-2

Odularu, G. O., \& Okonkwo, C. (2009). Does Energy Consumption Contribute to Economic Performance? Empirical Evidence from Nigeria. East-West Journal of Economic and Business, XII(2), 43-79.

Oguso, A. (2017). Growth Effects of Public Recurrent Expenditure in African countries. Journal of Economic, Management and Trade, 19(2), 1-20. https://doi.org/10.9734/JEMT/2017/36172

Omolo, O. J. (2010). The Dynamics and Trends of Employment in African countries. Presented at a Conference organized by the Institute of Economic Affairs, Nairobi, July 2010.

Pedroni, P. (2004). Panel co integration; Asymptotic and finite sample properties of pooled time series tests with an application to the PPP hypothesis. Econometric Theory, 20, 597-625. https://doi.org/10.1017/S0266466604203073

Perron. P. (1988). Testing for a Unit Root in Time Series Regression. Biomtrika, 75, 335-346. https://doi.org/10.1093/biomet/75.2.335

Pesaran, M. H. (2004). General diagnostic tests for cross section dependence in panels. Cambridge Working Papers in Economic , No. 0435.

Pesaran, M. H., Shin, Y., \& Smith, R. P. (2001). Bounds Testing Approaches to the Analysis of Level Relationships. Journal of Applied Econometrics, 16(3), 289-326. https://doi.org/10.1002/jae.616

Rodrguez, V. E. (1998). Recasting federalism in Mexico. Publius Journal of Federalism, 28, 235-254. https://doi.org/10.1093/oxfordjournals.pubjof.a029950 
Romer, D. H. (2001). Advanced Macroeconomic. Berkeley, the McGraw-Hill Co. Inc.

Solow, R. M. (1956). A contribution to the theory of Economic g Growth. The Quarterly Journal of Economic, 70(1), 65-94. https://doi.org/10.2307/1884513

Wagner, A. (1958). Three Extracts on public finance. In R. Musgrave, \& A. Peacock (Eds.), Classics in the Theory of Public Finance. London, Palgrave Macmillan. https://doi.org/10.1007/978-1-349-23426-4_1

Wahab, M. (2011). Asymmetric output growth effects of government spending: Panel data evidence. International Review of Economic and Finance, 20, 574-590. https://doi.org/10.1016/j.iref.2010.10.005

\section{Copyrights}

Copyright for this article is retained by the author(s), with first publication rights granted to the journal.

This is an open-access article distributed under the terms and conditions of the Creative Commons Attribution license (http://creativecommons.org/licenses/by/4.0/). 